\title{
ANALISA KRITIS: HAK KONSTITUSIONAL PROFESI GURU
}

\author{
Tri Wahyu Budiutomo \\ Pendidikan Pancasila dan Kewarganegaraan, Universitas Cokroaminoto Yogyakarta \\ Jl. Perintis Kemerdekaan, Gambiran, Pandeyan, Umbulharjo, Kota Yogyakarta 55161 \\ Email: tw.budiutomo@gmail.com
}

\begin{abstract}
ABSTRAK
Permasalahan hak konstitusional warga negara khususnya hak konstitusional guru dalam menjalankan tugas profesinya sangat menarik untuk dikaji secara mendalam. Banyak fenomena yang memprihatin terjadi pada guru dalam menjalankan tugas profesinya. Kerangka hukum sangat diperlukan bagi guru dalam menjalankan tugas profesinya. Hak konstkitusi merupakan hak hukum yang paling tinggi, bagaimana tahun 1945 telah dimanademen mampu memberikan jaminan perlindungan bagi guru dalam menjalankan tugas profesinya.

Hak konstitusional yang terkandung dalam UUD 1945 sebelum amandemen ada 7 pasal yang terdiri dari Pasal 27 ayat (2), Pasal 28, Pasal 29 (ayat (2), Pasal 30 ayat (1), Pasal 31 ayat (1) dan Pasal 32. Sedangkan setelah Amandemen Kedua tahun 2000, secara keseluruhan ketentuan materiil hak asasi manusia dalam UUD 1945, yang bila digabungkan dengan berbagai ketentuan yang terdapat dalam peraturan perundang-undangan yang berkaitan dengan hak asasi manusia, dapat dikelompokkan menjadi empat kelompok yang memuat 37 butir. ketentuan.

Guru merupakan profesi yang kelompok rentan mendapat perlakuan yang dapat mengganggu tugas profesinya, sehingga memerlukan perlakuan khusus untuk perlindungan akses dan pemenuhan hak konstitusional untuk menghindari kekerasan dan mencapai keadilan yang bermartabat. Hak konstitusional bagi guru dalam menjalankan tugas profesionalnya dijamin dalam UU Guru dan Dosen dan tersirat adanya perlindungan bagi guru dalam melaksanakan tugas profesionalnya yang meliputi: (1) perlindungan hukum; (2) perlindungan profesi: dan (3) perlindungan kesehatan dan keselamatan.
\end{abstract}

Kata Kunci: Hak Konstitusional, 1945, Guru

\begin{abstract}
Problems constitutional rights of citizens, especially the constitutional right of Master in performing the tasks their profession very interesting to be studied in depth. Many phenomena memprihatin happens to teachers in performing the duties of his profession. Legal framework is indispensable for teachers in carrying out the duties of his profession. Konstkitusi rights are the legal rights of the highest level, how 1945 has dimanademen able to give a guarantee of protection for teachers in carrying out the duties of his profession.

Constitutional rights contained in the 1945 Constitution before the amendment is 7 chapters that consist of Article 27 paragraph (2), article 28, article 29 (paragraph (2), Article 30 paragraph (1), Article 31 paragraph (1) and Article 32. Meanwhile, after the Second Amendment in 2000, the overall material provisions of the rights of human rights in the 1945 Constitution, which when combined with the various provisions contained in the legislation relating to human rights, can be grouped into four groups containing 37 grains provisions.

The teacher is a profession that vulnerable groups receive treatment that could interfere with the task of his profession, thus requiring special treatment for access protection and fulfillment of the constitutional right to avoid the violence and achieve justice with dignity. Constitutional rights for teachers in carrying out professional duties is guaranteed in the Law on Teachers and Lecturers and implied the existence of protection for teachers in implementing professional duties which include: (1) protection of the law; (2) the protection of the profession: and (3) the protection of health and safety
\end{abstract}

Keywords: Constitutional rights, 1945, Teacher 


\section{PENDAHULUAN}

Guru adalah pendidik profesional dengan tugas utama mendidik, mengajar, membimbing, mengarahkan, melatih, menilai, dan mengevaluasi peserta didik pada pendidikan anak usia dini jalur pendidikan formal, pendidikan dasar, dan pendidikan menengah. Demikian rumusan Pasal 1 ayat (1) Undang-undang Nomor 14 Tahun 2005 tentang Guru dan Dosen (penulis sebut "UUGD”). Pasal 39 ayat (1) UUGD menyebutkan bahwa "pemerintah, pemerintah daerah, masyarakat, organisasi profesi, dan/ atau satuan pendidikan wajib memberikan perlindungan terhadap guru dalam melaksanakan tugas. Selanjutnya pada pasal (2) disebutkan bahwa "perlindungan sebagaimana dimaksud pada ayat (1) meliputi perlindungan hukum, perlindungan profesi, serta perlindungan keselamatan dan kesehatan kerja. Pasal 39 ayat (1) UUGD merupakan pasal perlindungan guru dalam melaksanakan tugas profesinya.

Persoalannya adalah hingga saat ini belum ada peraturan pelaksanaan yang secara teknis operasional mengatur berbagai macam perlindungan terhadap guru, termasuk perlindungan hukumnya. Akibatnya, ketika dihadapkan pada kasus hukum tertentu, posisi guru acapkali menjadi sangat lemah. Dalam rangka melaksanakan tugas profesionalnya, guru di samping dihadapkan pada kewajiban untuk senantiasa meningkatkan profesionalisme, saat ini profesi guru juga dihadapkan pada tantangan yang semakin kompleks, seiring dengan adanya perubahan cara pandang masyarakat yang secara sadar terpengaruh oleh doktrin perlindungan hukum terhadap anak, termasuk anak didik. Dalam kasus-kasus tertentu, guru selain diadukan sebagai pelaku kekerasan terhadap siswa, dalam beberapa kasus justru menjadikan guru sebagai korban kekerasan dari siswa dan/atau orang tua siswa.

Pada kasus pertama, guru dilaporkan melanggar hak perlindungan anak ketika memberikan memberikan sanksi pelanggaran disiplin terhadap siswa, seperti dijewer, dipukul, dibentak, disuruh lari mengelilingi halaman sekolah, push up, dan sebagainya. Jenis-jenis hukuman disiplin seperti yang masa lampau dianggap biasa atau "lumrah" dalam dunia pendidikan, saat ini "dinilai" tidak lagi mendidik dan bahkan dianggap melanggar Undang-undang Perlindungan Anak.

Pada kasus kedua, guru menjadi korban kekerasan siswa atau orang tua siswa. Kasus kekerasan terhadap guru dalam bentuk pemukulan pada tahun 2015 lalu terjadi di sebuah SMA di Sukabumi, kasus kekerasan dalam bentuk pemukulan terhadap seorang guru SMK 
2 Makassar. Setelah sebelumnya, terjadi kasus di Jawa Timur yang berujung ke pengadilan, mestinya kasus semacam ini tidak terulang lagi.

Mengacu pada beberapa kasus di atas, terlihat bahwa posisi seorang guru sebagai tenaga pendidik seringkali berada pada posisi yang dilematis, antara tuntutan profesi dan perlakukan masyarakat. Di satu sisi, mereka dituntut untuk mampu mengantarkan peserta didik mencapai tujuan pendidikan. Namun disisi lain, pada saat para guru berupaya untuk menegakkan kedisplinan, mereka dihadang oleh UU Perlindungan Anak dan Komisi Perlindungan Anak Indonesia . Jika mereka gagal menegakkan kedisiplinan peserta didiknya dan gagal mengantarkan peserta didik pada pencapaian tujuan pendidikan, sebagai pendidik guru acapkali dituding menjadi penyebab atas kegagalan tersebut.

Persoalan yang paling krusial dihadapi oleh seorang guru adalah pada saat guru harus memberikan hukuman kepada peserta didik yang melanggar tata tertib dan aturan sekolah dalam rangka menegakkan kedisiplinan, acapkali orang tua dan masyarakat menilainya sebagai tindakan melanggar hak asasi manusia atau melanggar UU Perlindungan Anak. Mereka dengan mudahnya melaporkan tindakan guru tersebut kepada penegak hukum. Akibatnya, dalam menjalankan tugas profesinya guru seringkali berada pada posisi dilematis dan bahkan rentan untuk dikriminalisasi.

Persoalan kekerasan pada guru adalah persoalan yang terkait dengan perlindungan profesi dan hak konstitusi yang meliputi hak azasi manusia (HAM) dan hak warga negara yang dijamin dalam UUD 1945 ditegaskan bahwa setiap orang berhak untuk memperoleh dan memilih pekerjaan yang sah dan layak bagi kemanusiaan, dan setiap orang berhak untuk bekerja, mendapat imbalan, dan mendapat perlakuan yang layak dalam hubungan kerja yang berkeadilan. Hal tersebut dapat dilihat dari perumusannya yang menggunakan frasa "setiap orang", setiap warganegara, tiap-tiap warganegara atau setiap warganegara yang menunjukkan bahwa hak konstitusional dimiliki oleh setiap individu warganegara tanpa pembedaan, baik berdasarkan suku, agama, keyakinan politik maupun jenis kelamin. Hak-hak tersebut diakui dan dijamin untuk setiap warganegara baik laki-laki maupun perempuan.

Kekerasan terhdap guru dapat terjadi baik dalam konteks di ranah publik maupun domestik. Kekerasan terhadap guru dalam pelaksanaan tugas profesi yang mengakibatkan kesakitan fisik, psikis, mental termasuk ancaman pemaksaan atau perampasan kebebasan baik yang terjadi di lingkungan masyarakat maupun dalam kehidupan. Fenomena gunung es sesungguhnya dapat dilihat dalam pencatatan kasus-kasus kekerasan, karena tidak 
pernah dapat mewakili peristiwa yang sesungguhnya yang terjadi di masyarakat sehingga sangat dibutuhkan berbagai upaya dan strategi penanganan yang holistik komprehensif dengan melibatkan peran serta dari berbagai unsur dan potensi.

Permasalahan kekerasan pada guru dalam melaksanakan tugas profesinya adalah masalah yang sangat kompleks sehingga baik negara/pemerintah, LSM maupun swasta dan masyarakat diharapkan untuk memberikan penanganan secara komprehensif, holistik dan terpadu. Penegakan hak konstitusi yang tergambar melalui dominannya guru sebagai ujung tombak pelayanan kependidikan, memegang peranan penting dalam penanganan kondisi tersebut. Oleh karena itu, sangat diperlukan adanya pengetahuan guru tentang hak-hak konstitusional khususnya terkait dengan pelaksanaan tugas profesinya.

\section{HASIL DAN PEMBAHASAN}

\section{Hak Konstitusional Warga Negara}

Menurut Jimly Asshiddiqiem Hak konstitusional (constitutional right) adalah hakhak yang dijamin di dalam dan oleh UUD 1945. Setelah amandemen UUD 1945 yang merupakan konstitusi negara Indonesia maka prinsip-pinsip HAM telah tercantum dalam konsitusi Indonesia sebagai ciri khas prinsip konstitusi modern. Oleh karena itu prinsipprinsip HAM yang tercantum dalam UUD 1945 adalah merupakan Hak konstitusional Warga Negara Indonesia.

Dalam suatu negara hukum yang lahir dari konstitusionalisme harus bercirikan : (1) adanya perlindungan HAM, (2) adanya peradilan yang bebas dan (3) adanya asas legalitas. Oleh karena itu, hak konstitusional warga negara harus di jamin dalam konstitusi sebagai bentuk pengakuan HAM serta adanya peradilan yang independen tidak terpengaruh oleh penguasa dan segala tindakan pemerintahan harus didasarkan atas hukum.

Hak Asasi Manusia (HAM) adalah seperangkat hak yang melekat pada hakikat dan keberadaan setiap manusia sebagai makhluk Tuhan Yang Maha Esa dan merupakan anugerah-Nya yang wajib dihormati, dijunjung tinggi, dan dilindungi oleh Negara, Hukum, Pemerintahan, dan setiap orang, demi kehormatan serta perlindungan harkat dan martabat manusia. Artinya, yang dimaksud sebagai hak asasi manusia adalah hak yang melekat pada diri setiap pribadi manusia. Karena itu, hak asasi manusia (the human rights) itu berbeda dari pengertian hak warga negara (the citizen's rights). Hak warga negara adalah Hak-hak yang lahir dari peraturan di luar undang-undang dasar disebut hak-hak hukum (legal rights), bukan hak konstitusional (constitutional rights). Sedangkan Hak asasi Manusia yang terkandung dalam konstitusi dapat disebut sebagai hak konstitusional warga negara. 
Dalam pasal 26 UUD 1945 ayat (1) yang menjadi warga negara ialah orang-orang bangsa Indonesia asli dan orang-orang bangsa lain yang disahkan dengan undang-undang sebagai warga negara. Pengakuan hak konstitusional yang menjadi subyek adalah warga Negara Indonesia sehingga siapa pun yang diakui serta disahkan oleh undang-undang sebagai warga negara Indonesia maka mempunyai hak yang sama dalam bidang apa pun, entah mungkin sebelumnya adalah warga negara asing yang tinggal di Indonesia dengan masa tertentu dan mengusulkan untuk menjadi warga negara Indonesia maka akan memperoleh hak yang sama dengan bangsa Indonesia asli kecuali dalam kedudukannya sebagai calon Presiden dan wakil presiden harus orang Indonesia asli.

Pengertian-pengertian hak warga negara juga harus dapat dibedakan antara hak konstitusional dan hak legal. Hak kosntitusional (constitutional right) adalah hak-hak yang dijamin di dalam dan oleh UUD 1945, sedangkan hak-hak hukum (legal right) timbul berdasarkan jaminan undang-undang dan peraturan perundang-undangan dibawahnya (subordinate legislations). Setelah ketentuan tentang hak asasi manusia diadopsikan secara lengkap dalam UUD 1945, pengertian tentang hak asasi manusia dan hak asasi warga negara dapat dikaitkan dengan pengertian "constitutional rights" yang dijamin dalam UUD 1945. Selain itu, setiap warga negara Indonesia memiliki juga hak-hak hukum yang lebih rinci dan operasional yang diatur dengan undang-undang ataupun peraturan perundangundangan lain yang lebih rendah. Hak-hak yang lahir dari peraturan di luar undang-undang dasar disebut hak-hak hukum (legal rights), bukan hak konstitusional (constitutional rights).

Kaitan antara hak konstitusional dan HAM adalah ketika kita masukan bentukbentuk perlindungan Hak Asasi Manusia ke dalam konstitusi negara maka konsep HAM tersebut merupakan hak konstitusional dari setiap warga negara yang berada di wilayah suatu negara tertentu. Ditetapkannya Deklarasi Universal Hak Asasi Manusia (DUHAM) oleh Majelis umum pada tanggal 10 Desember 1948 merupakan langkah maju paling bersejarah dalam meningkatkan peradaban HAM di tataran nasional dan internasional. Deklarasi yang terdiri atas satu naskah gabungan ini mencakup hampir semua hak asasi dan kebebasan mendasar yang kita kenal sekarang.

Ketika komisi Hak Asasi Manusia Perserikatan Bangsa-Bangsa telah menyelesaikan pembuatan deklarasi ini dan membuat rancangan konvensi-konvensi hak asasi manusia yang akan mengikat secara hukum bagi negara-negara yang meratifikasinya, komisi tersebut mempertanyakan apakah sebaiknya dibuat satu atau dua kovenan. Pertanyaan ini 
dikembalikan kepada Majelis Umum yang dalam resolusi yang ditetapkan pada tahun 1950 menekankan sifat intradependensi semua kategori hak asasi manusia dan menyerukan agar komisi ini menetapkan konvensi terpisah. Akan tetapi tahun berikutnya, negara-negara barat dapat membalikkan keputusan tersebut dengan cara meminta Komisi Perserikatan Bangsa-Bangsa untuk membagi hak yang dimuat di dalam DUHAM menjadi dua kovenan internasional yang terpisah, yaitu satu kovenan tentang hak sipil dan politik (SIPOL) dan kovenan lain tentang hak ekonomi, sosial dan budaya (EKOSOSBUD). Hasilnya, umumnya Piagam Hak Asasi Manusia dianggap secara keseluruhan memiliki dua kategori hak asasi manusia yang berbeda. Hak sipil dan politik (1) dan Hak Ekonomi, sosial dan budaya.

Indonesia merupakan negara yang turut meratifikasi Kovenan hak sipil dan politik serta hak ekonomi, sosial dan budaya dengan keluarnya Undang-Undang Nomor 39 Tahun 1999 tentang Hak Asasi Manusia. Undang-Undang No.39 Tahun 1999 tentang Hak Asasi Manusia merupakan jaminan pengakuan HAM oleh negara terhadap warga negara Indonesia sehingga dalam pelaksanaan pemerintahan dapat melindungi hak-hak warga negara.

Dalam amandemen UUD 1945 atau konstitusi Indonesia telah mengakui prinsipprinsip Hak Asasi Manusia (HAM) seperti hak untuk hidup, hak untuk tidak disiksa, hak kemerdekaan pikiran dan hati nurani, hak beragama, hak untuk tidak diperbudak, hak untuk diakui sebagai pribadi dihadapan hukum, dan hak untuk tidak dituntut atas dasar hukum yang berlaku surut adalah hak asasi manusia yang tidak dapat dikurangi dalam bentuk apa pun.

Dasar keberadaan konstitusi adalah kesepakatan umum atau persetujuan (consensus) diantara mayoritas rakyat mengenai bangunan yang diidealkan berkenaan dengan negara. Konstitusi merupakan konsensus bersama atau general agreement seluruh warga negara. Organisasi negara itu diperlukan oleh warga masyarakat politik agar kepentingan mereka bersama dapat dilindungi atau dipromosikan melalui pembentukan dan penggunaan mekanisme yang disebut negara.

Kepentingan paling mendasar dari setiap warga negara adalah perlindungan terhadap hak-haknya sebagai manusia. Oleh karena itu, Hak asasi manusia merupakan materi inti dari naskah undang-undang dasar negara modern. Hak Asasi Manusia (HAM), adalah seperangkat hak yang melekat pada hakikat dan keberadaan setiap manusia sebagai makhluk Tuhan Yang Maha Esa dan merupakan anugerah-Nya yang wajib dihormati, 
dijunjung tinggi, dan dilindungi oleh Negara, Hukum, Pemerintahan, dan setiap orang, demi kehormatan serta perlindungan harkat dan martabat manusia. Artinya, yang dimaksud sebagai hak asasi manusia adalah hak yang melekat pada diri setiap pribadi manusia.

Keterkaitan antara konstitusi dengan hak asasi manusia juga dapat dilihat dari perkembangan sejarah. Perjuangan perlindungan hak asasi manusia selalu terkait dengan perkembangan upaya pembatasan dan pengaturan kekuasaan yang merupakan ajaran konstitusionalisme. Magna Charta (1215) dan Petition of Rights (1628) adalah momentum perlindungan hak asasi manusia sekaligus pembatasan kekuasaan raja oleh kekuasaan parlemen (house of commons).

Dalam konteks hak asasi manusia, Thomas Hobbes melihat bahwa hak asasi manusia merupakan jalan keluar untuk mengatasi keadaan yang disebutnya "homo homini lupus, bellum omnium contra omnes" . Dalam keadaan demikian, manusia tak ubahnya bagaikan binatang buas dalam legenda kuno yang disebut 'Leviathan' yang dijadikan oleh Thomas Hobbes sebagai judul buku.

Keadaan seperti itulah yang, menurut Hobbes, mendorong terbentuknya perjanjian masyarakat dalam mana rakyat menyerahkan hak-haknya kepada penguasa. Itu sebabnya pandangan Thomas Hobbes disebutkan sebagai teori yang mengarah kepada pembentukan monarki absolut. Sebaliknya, John Locke berpendapat bahwa manusia tidaklah secara absolut menyerahkan hak-hak individunya kepada penguasa. Yang diserahkan, menurutnya, hanyalah hak-hak yang berkaitan dengan perjanjian negara semata, sedangkan hak-hak lainnya tetap berada pada masing-masing individu.

Dengan demikian Konstitusi dan HAM saling terikat dan tidak dapat dipisahkan karena pembentukan suatu negara merupakan kesepakatan atau persetujuan masyarakat yang menginginkan hak-haknya lebih terjamin, tertib, serta aman dan terhindar dari homo homini lupus.

\section{Landasan berlakunya HAM dalam konstitusi Indonesia}

Indonesia merupakan negara ke-60 yang resmi menjadi anggota PBB, pada tanggal 28 September 1950. Hanya kurang dari setahun sejak pengakuan kedaulatan melalui Konferensi Meja Bundar (KMB). Posisi Indonesia di dunia internasional terus menguat. Diplomat Indonesia yangditunjuk menjadi kepala Perwakilan Tetap pertama di PBB adalah L.N. Palar.

Selama bergabung dengan PBB, prestasi Indonesia cukup instimewa. Indonesia tercatat berpartisipasi aktif dengan mengirim misi perdamaian melalui Kontingen Garuda, 
menjabat anggota tidak tetap Dewan Keamanan dua kali, ketua Komisi HAM PBB satu kali, dan rektor Universitas PBB satu kali. Keanggotaan Indonesia dalam Perserikatan Bangsa-Bangsa inilah membuat setiap peraturan Internasional yang disepakati bersama dalam forum Perserikatan Bangsa-Bangsa ini diakui dalam setiap peraturan perundangundangan di Indonesia, Salah satunya adalah deklarasi Universal Hak Asasi Manusia. Kovenan hak sipil dan politik serta Hak ekonomi, sosial dan budaya turut diratifikasi dalam Peraturan perundang-undangan di Indonesia.

Dengan adanya amandemen UUD 1945 yang mengakui Hak Konstitusional warga negara dalam konsep HAM turut membawa andil keluarnya UU No. 39 tahun 1999 tentang Hak Asasi Manusia. Hak Asasi Manusia membawa perubahan dalam tatanan pemerintahan serta tatanan berkehidupan kebangsaan. Dahulu pemerintahan yang super power serta sentralistik tetapi dengan hadirnya Hak Asasi Manusia ini membuat negara tidak dapat sewenang-wenang melakukan suatu tindakan yang melanggar Hak Asasi warga negara.

\section{Hak Konstitusional yang terkandung dalam UUD 1945}

\section{a. Sebelum amandemen UUD 1945}

Dalam UUD 1945 sering disebut dengan UUD Proklamasi, dan kemunculannya bersamaan dengan lahirnya Negara Indonesia melalui proklamasi kemerdekaan, satu hal yang menarik meskipun UUD 1945 adalah hukum dasar yang tertulis yang didalamnya memuat hak-hak dasar manusia Indonesia serta kewajibannya yang bersifat dasar pula, namun istilah perkataan HAM itu sendiri tidak dijumpai didalam UUD 1945 , baik dalam pembukaan, batang tubuh maupun penjelasan dan yang ditemukan bukanlah HAM melainkan Hak dan kewajiban warganegara.

Sebelum amandemen UUD 1945 memuat hak warga negara sebagai berikut:

“-Pasal 27 ayat (1): setiap warga negara bersamaan kedudukannya di dalam hukum dan penerintahan dan wajib menjunjung hukum dan pemerintahan itu dengan tidak ada kecualinya.

- Pasal 27 ayat (2): tiap-tiap warga negara berhak atas pekerjaan dan penghidupan yang layak bagi kemanusiaan.

- Pasal 28: kemerdekaan berserikat dan berkumpul, mengeluarkan pikiran dengan lisan dan tulisan dan sebagainya ditetapkan dengan undang-undang.

- Pasal 29 ayat (2): negara menjamin kemerdekaan tiap-tiap penduduk untuk memeluk agamanya masing-masing dan untuk beribadat menurut agamanya dan kepercayaannya itu. 
- Pasal 30 ayat (1): tiap-tiap warga negara berhak dan wajib ikut serta dalam usaha pembelaan negara.

- Pasal 31 ayat (1): tiap-tiap warga negara berhak mendapat pengajaran.

- Pasal 32: pemerintah memajukan kebudayaan nasional Indonesia”.

Ketika UUD 1945 digantikan oleh Konstitusi RIS 1949 atau yang lebih tepat disebut sebagai UUD RIS 1949, dan kemudian UUDS Tahun 1950, kedua naskah undang-undang dasar ini memuat ketentuan yang lebih lengkap tentang hak asasi manusia.

Dalam perumusan naskah UUD-RIS 1949 dan UUDS 1950 ,Soepomo yang semula, ketika UUD 1945 dirumuskan, menentang pencantuman pasal-pasal tentang hak asasi manusia. Artinya, setelah tahun 1948, pandangan dan apresiasi Soepomo dan juga Soekarno turut pula mengalami perkembangan sehubungan dengan ketentuan konstitusional hak asasi manusia itu sendiri. Hal ini terjadi, karena ketika itu The Universal Declaration of Human Rights Tahun 1948 sudah ada, dan sedang sangat populer di dunia. Sayangnya, Undang-Undang Dasar 1950 tidak berlaku lagi sejak tanggal 5 Juli 1959. Mulai saat itu berlakulah kembali Undang-Undang Dasar 1945 yang hanya memuat 7 pasal tentang hak asasi manusia. Itu pun dalam pengertiannya yang sangat terbatas. Bahkan sebenarnya, menurut Harun Alrasid, UUD 1945 itu sama sekali tidak memberikan jaminan apa pun mengenai hak-hak asasi manusia. Menurutnya, yang diperdebatkan antara Hatta-Yamin di satu pihak dan Soekarno-Soepomo di lain pihak, hanya berkenaan dengan substansi Pasal 28 yang akhirnya sebagai kompromi disepakati berbunyi, "Kemerdekaan berserikat dan berkumpul, mengeluarkan pikiran dengan lisan dan tulisan dan sebagainya ditetapkan dengan undang-undang”.

Muhammad Hatta dan Muhammad Yamin sudah mengusulkan pencantuman jaminan hak asasi manusia disini, tetapi oleh Soekarno dan Soepomo ditolak karena hal itu mereka anggap bertentangan dengan paham integralistik. Karena itu, sebagai jalan tengahnya disepakatilah rumusan yang demikian itu. Akan tetapi, jika diamati secara seksama, Pasal 28 itu sama sekali tidak memberikan jaminan mengenai adanya pengakuan konstitusional akan hak dan kebebasan berserikat (freedom of association), berkumpul (freedom of assembly), dan menyatakan pendapat (freedom of expression). Pasal 28 itu hanya menyatakan bahwa hak-hak tersebut akan 
ditetapkan dengan undang-undang. Artinya, sebelum ditetapkan dengan undangundang, hak itu sendiri belum ada.

Dengan demikian pengakuan hak konstitusional dalam UUD 1945 sebelum amandemen belum mengakui HAM sebagai hak konstitusional tetapi hanya mengatur hak dan kewajiban warga negara.

\section{b. Pasca Amandemen UUD 1945}

Sekarang, setelah amendemen UUD 1945 lebih banyak mengakui bentuk-bentuk HAM sebagai hak kostitusional warga ngara Indonesia. Materi yang semula hanya berisi 7 butir ketentuan yang juga tidak seluruhnya dapat disebut sebagai jaminan konstitusional hak asasi manusia, sekarang telah bertambah secara sangat signifikan.

Ketentuan baru yang diadopsikan ke dalam UUD 1945 setelah Perubahan Kedua pada tahun 2000 termuat dalam Pasal 28A sampai dengan Pasal 28J, ditambah beberapa ketentuan lainnya yang tersebar di beberapa pasal. Karena itu, perumusan tentang hak-hak asasi manusia dalam konstitusi Republik Indonesia dapat dikatakan sangat lengkap dan menjadikan UUD 1945 sebagai salah satu undang-undang dasar yang paling lengkap memuat ketentuan yang memberikan perlindungan terhadap hak-hak asasi manusia.

Pasal-pasal tentang hak asasi manusia itu sendiri, terutama yang termuat dalam Pasal 28A sampai dengan Pasal 28J, pada pokoknya berasal dari rumusan TAP MPR Nomor XVII/MPR/1998 tentang Hak Asasi Manusia yang kemudian isinya menjadi materi UU Nomor 39 Tahun 1999 tentang Hak Asasi Manusia. Oleh karena itu, untuk memahami konsepsi tentang hak-hak asasi manusia itu secara lengkap dan historis, ketiga instrumen hukum UUD 1945, TAP MPR Nomor XVII/MPR/1998 dan UU Nomor 39 Tahun 1999 tentang Hak Asasi Manusia tersebut dapat dilihat dalam satu kontinum. Secara keseluruhan dapat dikatakan bahwa ketentuanketentuan tentang hak-hak asasi manusia yang telah diadopsikan ke dalam sistim hukum dan konstitusi Indonesia itu berasal dari berbagai konvensi internasional dan deklarasi universal tentang hak asasi manusia serta berbagai instrumen hukum internasional lainnya.

Setelah Perubahan Kedua pada tahun 2000, keseluruhan materi ketentuan hakhak asasi manusia dalam UUD 1945, yang apabila digabung dengan berbagai ketentuan yang terdapat dalam undang-undang yang berkenaan dengan hak asasi manusia, dapat kita kelompokkan dalam empat kelompok yang berisi 37 butir 
ketentuan. Diantara keempat kelompok hak asasi manusia tersebut, terdapat hak asasi manusia yang tidak dapat dikurangi dalam keadaan apapun atau non-derogable rights, yaitu:

“1) Hak untuk hidup;

2) Hak untuk tidak disiksa;

3) Hak kemerdekaan pikiran dan hati nurani;

4) Hak beragama;

5) Hak untuk tidak diperbudak;

6) Hak untuk diakui sebagai pribadi di hadapan hukum; dan

7) Hak untuk tidak dituntut atas dasar hukum yang berlaku surut".

Sedangkan keempat kelompok hak asasi manusia terdiri atas; kelompok pertama adalah kelompok ketentuan yang menyangkut hak-hak sipil yang meliputi:

“1) Setiap orang berhak untuk hidup, mempertahankan hidup dan kehidupannya;

2) Setiap orang berhak untuk bebas dari penyiksaan, perlakuan atau penghukuman lain yang kejam, tidak manusiawi dan merendahkan martabat kemanusiaan ;

3) Setiap orang berhak untuk bebas dari segala bentuk perbudakan;

4) Setiap orang bebas memeluk agama dan beribadat menurut agamanya;

5) Setiap orang berhak untuk bebas memiliki keyakinan, pikiran, dan hati nurani;

6) Setiap orang berhak untuk diakui sebagai pribadi di hadapan hukum;

7) Setiap orang berhak atas perlakuan yang sama di hadapan hukum dan pemerintahan;

8) Setiap orang berhak untuk tidak dituntut atas dasar hukum yang berlaku surut;

9) Setiap orang berhak untuk membentuk keluarga dan melanjutkan keturunan melalui perkawinan yang sah;

10) Setiap orang berhak atas status kewarganegaraan;

11) Setiap orang berhak untuk bertempat tinggal di wilayah negaranya, meninggalkan, dan kembali ke negaranya;

12) Setiap orang berhak memperoleh suaka politik;

13) Setiap orang berhak bebas dari segala bentuk perlakuan diskriminatif dan berhak mendapatkan perlindungan hukum dari perlakuan yang bersifat diskriminatif tersebut “. 
Kedua, kelompok hak-hak politik, ekonomi, sosial, dan budaya yang meliputi:

“1) Setiap warga negara berhak untuk berserikat, berkumpul dan menyatakan pendapatnya secara damai dengan lisan dan tulisan;

2) Setiap warga negara berhak untuk memilih dan dipilih dalam rangka lembaga perwakilan rakyat;

3) Setiap warga negara dapat diangkat untuk menduduki jabatan-jabatan publik;

4) Setiap orang berhak untuk memperoleh dan memilih pekerjaan yang sah dan layak bagi kemanusiaan;

5) Setiap orang berhak untuk bekerja, mendapat imbalan, dan mendapat perlakuan yang layak dalam hubungan kerja yang berkeadilan;

6) Setiap orang berhak mempunyai hak milik pribadi;

7) Setiap warga negara berhak atas jaminan sosial yang dibutuhkan untuk hidup layak dan memungkinkan pengembangan dirinya sebagai manusia yang bermartabat;

8) Setiap orang berhak untuk berkomunikasi dan memperoleh informasi;

9) Setiap orang berhak untuk memperoleh dan memilih pendidikan dan pengajaran;

10) Setiap orang berhak mengembangkan dan memperoleh manfaat dari ilmu pengetahuan dan teknologi, seni dan budaya untuk peningkatan kualitas hidup dan kesejahteraan umat manusia;

11) Negara menjamin penghormatan atas identitas budaya dan hak-hak masyarakat lokal selaras dengan perkembangan zaman dan tingkat peradaban bangsabangsa;

12) Negara mengakui setiap budaya sebagai bagian dari kebudayaan nasional;

13) Negara menjamin kemerdekaan tiap-tiap penduduk untuk memeluk agamanya masing-masing, dan untuk beribadat menurut kepercayaannya itu".

Ketiga, kelompok hak-hak khusus dan hak atas pembangunan yang meliputi:

“1) Setiap warga negara yang menyandang masalah sosial, termasuk kelompok masyarakat yang terasing dan yang hidup di lingkungan terpencil, berhak mendapat kemudahan dan perlakuan khusus untuk memperoleh kesempatan yang sama;

2) Hak perempuan dijamin dan dilindungi untuk mendapai kesetaraan gender dalam kehidupan nasional; 
3) Hak khusus yang melekat pada diri perempuan uang dikarenakan oleh fungsi reproduksinya dijamin dan dilindungi oleh hukum;

4) Setiap anak berhak atas kasih sayang, perhatian, dan perlindungan orangtua, keluarga, masyarakat dan negara bagi pertumbuhan fisik dan mental serta perkembangan pribadinya;

5) Setiap warga negara berhak untuk berperan-serta dalam pengelolaan dan turut menikmati manfaat yang diperoleh dari pengelolaan kekayaan alam;

6) Setiap orang berhak atas lingkungan hidup yang bersih dan sehat;

7) Kebijakan, perlakuan atau tindakan khusus yang bersifat sementara dan dituangkan dalam peraturan perundang-undangan yang sah yang dimaksudkan untuk menyetarakan tingkat perkembangan kelompok tertentu yang pernah mengalami perlakuan diskriminatif dengan kelompok-kelompok lain dalam masyarakat, dan perlakuan khusus tersebut tidak termasuk dalam pengertian diskriminasi."

Keempat, kelompok yang mengatur mengenai tanggungjawab negara dan kewajiban asasi manusia yang meliputi:

“1) Setiap orang wajib menghormati hak asasi manusia orang lain dalam tertib kehidupan bermasyarakat, berbangsa, dan bernegara;

2) Dalam menjalankan hak dan kebebasannya, setiap orang wajib tunduk pada pembatasan yang ditetapkan oleh undang-undang dengan maksud semata-mata untuk menjamin pengakuan dan penghormatan atas hak dan kebebasan orang lain serta untuk memenuhi tuntutan keadilan sesuai dengan nilai-nilai agama, moralitas, dan kesusilaan, keamanan, dan ketertiban umum dalam masyarakat yang demokratis;

3) Negara bertanggungjawab atas perlindungan, pemajuan, penegakan, dan pemenuhan hak-hak asasi manusia;

4) Untuk menjamin pelaksanaan hak asasi manusia, dibentuk Komisi Nasional Hak Asasi Manusia yang bersifat independen dan tidak memihak yang pembentukan, susunan, dan kedudukannya diatur dengan undang-undang.

Hak-hak tersebut di atas ada yang termasuk kategori hak asasi manusia yang berlaku bagi semua orang yang tinggal dan berada dalam wilayah hukum Republik Indonesia, dan ada pula yang merupakan hak warga negara yang berlaku hanya bagi warga negara Republik Indonesia. Hak-hak dan kebebasan tersebut ada yang 
tercantum dalam UUD 1945 dan ada pula yang tercantum hanya dalam undangundang tetapi memiliki kualitas yang sama pentingnya secara konstitusional sehingga dapat disebut memiliki "constitutional importance" yang sama dengan yang disebut eksplisit dalam UUD 1945. Sesuai dengan prinsip "kontrak sosial” (social contract), maka setiap hak yang terkait dengan warga negara dengan sendiri bertimbal-balik dengan kewajiban negara untuk memenuhinya. Demikian pula dengan kewenangankewenangan konstitusional yang dimiliki oleh negara melalui organ-organnya juga bertimbal-balik dengan kewajiban-kewajiban konstitusional yang wajib ditaati dan dipenuhi oleh setiap warga negara.

\section{Pengakuan Hak Konstitusional yang dijamin UUD 1945}

Sejak berdirinya Negara Republik Indonesia, dilihat dari perkembangan berdemokrasi serta kehidupan berkebangsaan dimana dalam konstitusi kita mengakui hak kostitusional setiap warga negara. Hak konstitusional dalam UUD 1945 antara lain:

Beberapa hal pokok yang terkait dengan hak konstitusional guru dalam melaksanakan tugas profesinya dalam UUD 1945 antara lain adalah:

a. Hak untuk hidup. Apakah setiap warga negara telah terjamin rasa aman? Dengan kejadian terorisme yang terjadi di Indonesia membuat rasa tidak aman menghantui sebagian warga Indonesia. banyak negara-negara yang memasang "travel warning" untuk kunjungan ke Indonesia. juga adanya hukuman mati dalam hukum pidana Indonesia bertentangan dengan hak untuk hidup dalam konstitusi RI.

b. Hak untuk memperoleh pendidikan. Apakah setiap anak usia wajib belajar telah menikmati pendidikan? Apakah setiap guru telah merasa nyaman dan aman dalam melaksanakan tugas profesinya mendidik anak didik. Pemerintah berkewajiban untuk membuat pendidikan tersedia (available), mudah dicapai (accessible), diterima (acceptable) dan dapat beradaptasi (adaptable):

c. Available (ketersediaan) mewujudkan dua kewajiban pemerintah yang berbeda: hak atas pendidikan sebagai sebuah hak sipil dan politik membuat pemerintah harus membangun sekolah-sekolah, sementara hak atas pendidikan sebagai hak social, ekonomi dan budaya mengharuskan pemerintah harus memastikan bahwa pendidikan yang wajib dan gratis tersedia untuk semua anak-anak usia sekolah.

d. Access (akses) didefinisikan secara berbeda untuk tingkatan pendidikan yang berbeda. Pemerintah wajib menjamin akses pada pendidikan untuk semua anak dalam kisaran 
usia wajib belajar, untuk semua guru untuk dapat melaksanakan tugas profesinya dengan baik.

e. Acceptability (dapat diterima) membutuhkan suatu jaminan kualitas pendidikan, standar minimum kesehatan dan keamanan, atau kriteria-kriteria professional dari para guru yang harus dibuat, dimonitor dan ditegakkan oleh pemerintah. Konsep dapat diterima telah cukup diperluas lewat perkembangan hukum hak asasi manusia internasional: hak masyarakat adat dan minoritas telah memprioritaskan bahasa pengantar; pelarangan hukuman badan telah mentransformasi disiplin di sekolah. Munculnya anak sebagai subyek dari hak atas pendidikan dan hak dalam pendidikan telah lebih jauh memperbesar batasan dari dijaminnya dapat diterimanya pendidikan.

f. Adaptability (kemampuan beradaptasi) membutuhkan sekolah untuk beradaptasi dengan para anak, mengikuti ukuran kepentingan setiap anak dalam konvensi tentang hak-hak anak. Dengan melihat hak warga negara untuk memperoleh pendidikan, maka pemerintah mengusahakan dengan memprioritaskan anggaran pendidikan sekurangkurangnya $20 \%$ dalam APBN sehingga kiranya dapat menjamin setiap anak usia wajib belajar dapat memperoleh pendidikan.

g. Setiap orang berhak untuk bekerja, mendapat imbalan, dan mendapat perlakuan yang layak dalam hubungan kerja yang berkeadilan yang bermartabat; bagaimana dengan nasib para guru yang sedang bertugas melaksanakan tugas profesinya. Pemerintah harus menjamin perlindungan hak-hak profesi guru.

\section{Kompetensi Guru}

Berdasarkan Undang-Undang Nomor 14 Tahun 2005 tentang Guru dan Dosen, pada pasal 10 ayat (1) menyatakan bahwa:

"Kompetensi guru sebagaimana dimaksud dalam Pasal 8 meliputi kompetensi pedagogik, kompetensi kepribadian, kompetensi sosial, dan kompetensi profesional yang diperoleh melalui pendidikan profesi”

\section{a. Kompetensi Pedagogik}

Kompetensi Pedagogik adalah kemampuan pemahaman terhadap peserta didik, perancangan dan pelaksanaan pembelajaran, evaluasi hasil belajar, dan pengembanganpeserta didik untuk mengaktualisasikan berbagai potensi yang dimilikinya. Sub kompetensi dalam kompetensi Pedagogik adalah: 
1) Memahami peserta didik secara mendalam yang meliputi memahami peserta didik dengan memamfaatkan prinsip-prinsip perkembangan kognitif, prinsip-prinsip kepribadian, dan mengidentifikasi bekal ajar awal peserta didik.

2) Merancang pembelajaran, teermasuk memahami landasan pendidikan untuk kepentingan pembelajaran yang meliputi memahmi landasan pendidikan, menerapkan teori belajar dan pembelajaran, menentukan strategi pembelajaran berdasarkan karakteristik peserta didik, kompetensi yang ingin dicapai, dan materi ajar, serta menyusun rancangan pembelajaran berdasarkan strategi yang dipilih.

3) Melaksanakan pembelajaran yang meliputi menata latar ( setting) pembelajaran dan melaksanakan pembelajaran yang kondusif.

4) Merancang dan melaksanakan evaluasi pembelajaran yang meliputi merancang dan melaksanakan evaluasi (assessment) proses dan hasil belajar secara berkesinambungan denga berbagai metode,menganalisis hasil evaluasi proses dan hasil belajar untuk menentukan tingkat ketuntasan belajar (mastery level), dan memamfaatkan hasil penilaian pembelajaran untuk perbaikan kualitas program pembelajaran secara umum.

5) Mengembangkan peserta didik untuk mengaktualisasikan berbagai potensinya meliputi memfasilitasi peserta didik untuk pengembangan berbagai potensi akademik, dan memfasilitasipeserta didik untuk mengembangkan berbagai potensi nonakademik.

\section{b. Kompetensi Kepribadian}

Kompetensi Kepribadian adalah kemampuan personal yang mencerminkan kepribadian yang mantap, stabil, dewasa, arif dan berwibawa, menjadi teladan bagi peserta didik, dan berakhlak mulia. Sub kompetensi dalam kompetensi kepribadian meliputi :

1) Kepribadian yang mantap dan stabil meliputi bertindak sesuai dengan norma sosial, bangga menjadi guru, dan memiliki konsistensi dalam bertindak sesuai dengan norma.

2) Kepribadian yang dewasa yaitu menampilkan kemandirian dalam bertindak sebagaipendidik dan memiliki etod kerja sebagai guru.

3) Kepribadian yang arif adalah menampilkan tindakan yang didasarkan pada kemamfaatan peserta didik, sekolah dan masyarakat dan menunjukkan keterbukaan dalam berpikir dan bertindak. 
4) Kepribadian yang berwibawa meliputi memiliki perilaku yang berpengaruh positif terhadappeserta didik dan memiliki perilaku yangh disegani.

5) Berakhlak mulia dan dapat menjadi teladan meliputibertindak sesuai dengan norma religius (imtaq, jujur, ikhlas, suka menolong) dan memiliki perilaku yang diteladani peserta didik.

\section{c. Kompetensi Profesional}

Kompetensi Profesional adalah penguasaan materi pembelajaran secara luas dan mendalam, yang mencakup penguasaan materi kurikulum mata pelajaran di sekolah dan substansi keilmuan yang menaungi materinya, serta penguasaan terhadap struktur dan metodologi keilmuannya.

1) Menguasai materi, struktur, konsep, dan pola pikir keilmuan yang mendukung pelajaran yang dimampu.

2) Mengusai standar kompentensi dan kompetensi dasar mata pelajaran/bidang pengembangan yang dimampu.

3) Mengembangkan materi pembelajaran yang dimampu secara kreatif.

4) Mengembangkan keprofesionalan secara berkelanjutan dengan melakukan tindakan reflektif.

5) Memanfaatkan TIK untuk berkomunikasi dan mengembangakan diri.

\section{d. Kompetensi Sosial}

Kompetensi Sosial adalah kemampuan guru untuk berkomunikasi dan bergaul secara efektif dengan peserta didik, tenaga kependidikan, orang tua/wali peserta didik, dan masyarakat sekitar.

1) Bersikap inkulif, bertindak obyektif, serta tidak diskriminatif karena pertimbangan jeniskelamin, agara, raskondisifisik, latar belakang keluarga, dan status sosial keluarga.

2) Berkomunikasi secara efektif, empatik, dan santun dengan sesama pendidik, tenaga kependidikan, orang tua dan masyarakat.

3) Beradaptasi di tempat bertugas di seluruh wilayah RI yang memiliki keragaman social budaya.

4) Berkomunikasi dengan lisan maupun tulisan

\section{Implikasi Hak Konstitusional Bagi guru Dalam Melaksanakan tugas Profesinya}

Hak konstitusional bagi guru dalam melaksanakan tugas profesinya diimplikasikan dengan adanya perlindungan bagi guru dalam melaksanakan tugas profesinya meliputi: (1) 
perlindungan hukum; (2) perlindungan profesi; dan (3) perlindungan keselamatan dan kesehatan kerja Perlindungan tersebut didapatkan dari: (1) pemerintah; (2) pemerintah daerah;(3) masyarakat; (4) organisasi profesi;dan (4) satuan pendidikan tempat guru mengajar.

Sebagaimana disebutkan pada Undang-undang nomor 14 tahun 2005 tentang Guru dan Dosen pasal 39:

a. Pemerintah, pemerintah daerah, masyarakat, organisasi profesi, dan/atau satuan pendidikan wajib memberikan perlindungan terhadap guru dalam pelaksanaan tugas.

b. Perlindungan sebagaimana dimaksud pada ayat (1) meliputi perlindungan hukum, perlindungan profesi, serta perlindungan keselamatan dan kesehatan kerja.

c. Perlindungan hukum sebagaimana dimaksud pada ayat (2) mencakup perlindungan hukum terhadap tindak kekerasan, ancaman, perlakuan diskriminatif, intimidasi, atau perlakuan tidak adil dari pihak peserta didik, orang tua peserta didik, masyarakat, birokrasi, atau pihak lain.

d. Perlindungan profesi sebagaimana dimaksud pada ayat (2) mencakup perlindungan terhadap pemutusan hubungan kerja yang tidak sesuai dengan peraturan perundangundangan, pemberian imbalan yang tidak wajar, pembatasan dalam penyampaian pandangan, pelecehan terhadap profesi, dan pembatasan/pelarangan lain yang dapat menghambat guru dalam melaksanakan tugas.

e. Perlindungan keselamatan dan kesehatan kerja sebagaimana dimaksud pada ayat (2) mencakup perlindungan terhadap risiko gangguan keamanan kerja, kecelakaan kerja, kebakaran pada waktu kerja, bencana alam, kesehatan lingkungan kerja, dan/atau risiko lain.

\section{SIMPULAN}

Berdasarkan uraian yang telah dikemukakan di atas, maka dapat disimpulkan beberapa hal sebagai berikut:

a. Hak konstitusional merupakan hak warga negara yang dijamin dalam dan oleh UUD 1945 sehingga merupakan amanat yang harus dijalankan oleh pemerintah Republik Indonesia. Oleh karena itu, hak konstitusional warga negara harus di jamin dalam konstitusi sebagai bentuk pengakuan HAM serta adanya peradilan yang independen tidak terpengaruh oleh penguasa dan segala tindakan pemerintahan harus didasarkan atas hukum. Setiap hak asasi manusia (human rights) tidak selamanya merupakan hak 
konstitusional (constitutional rights) tetapi jika prinsip-prinsip HAM diakui dalam konstitusi suatu negara maka prinsip-prinsip HAM tersebut merupakan hak konstitusional warga negara.

b. Hak konstitusional yang terkandung dalam UUD 1945 sebelum amandemen adalah 7 pasal yang terdiri dari pasal 27 ayat (2), pasal 28, pasal 29 (ayat (2), pasal 30 ayat (1), pasal 31 ayat (1) dan pasal 32. Sedangkan setelah Perubahan Kedua pada tahun 2000, keseluruhan materi ketentuan hak-hak asasi manusia dalam UUD 1945, yang apabila digabung dengan berbagai ketentuan yang terdapat dalam undang-undang yang berkenaan dengan hak asasi manusia, dapat kita kelompokkan dalam empat kelompok yang berisi 37 butir ketentuan.

c. Guru merupakan kelompok profesi yang rentan mendapatkan perlakuan yang dapat menggangu tugas profesinya, sehingga membutuhkan perlakuan khusus untuk mengakses perlindungan dan pemenuhan hak konstitusional agar terhindar dari tindak kekerasan dan dapat mencapai keadilan yang bermartabat.

d. Hak konstitusional bagi guru dalam melaksanakan tugas profesinya dijamin dalam UU Guru dan Dosen dan diimplikasikan dengan adanya perlindungan bagi guru dalam melaksanakan tugas profesinya yang meliputi:

1) perlindungan hukum

2) perlindungan profesi

3) perlindungan keselamatan dan kesehatan kerja

\section{SARAN}

Dari simpulan yang dikemukakan diatas, maka dapatlah disarankan beberapa hal sebagai berikut:

a. Pendidikan aparatur penegak hukum harus bisa menumbuhkan komitmen aparat penegak hukum terhadap penyelenggaraan peradilan yang bebas serta independen dan tidak terpengaruh dengan kekuasaan.

b. Prinsip HAM sebagai hak konstitusional bagi guru dalam melaksanakan tugas profesinya yang diakui dalam UUD 1945 harus benar-benar dilaksanakan oleh pemerintah Republik Indonesia.

c. Pemerintah wajib menerbitkan aturan pelaksanaan dan teknis tentang perlindungan guru dan dosen. 


\section{DAFTAR PUSTAKA}

Absbjorn Eide, Catarina Krause dan Allan Rosas, Hak Ekonomi, social dan budaya, Raoul Wallenberg Institute Of Human Rights and Humanitarian Law.

Adnan Buyung Nasution, Aspirasi Pemerintahan Konstitusional di Indonesia, Pustaka Utama Grafiti, Jakarta, 1995.

Andrews, William G, Constitutions and Constitutionalism. 3rd edition. New Jersey: Van Nostrand Company, 1968.

Asshidiqie, jimly, 2008, Konstitusi dan Hak Asasi Manusia, diakses 14 September 2020 link: http://click-gtg.blogspot.com/2008/08/konstitusidanhakasasimanusia_04.html

Bachr, Peter, Pieter van Dijk, dan Adnan Buyung Nasution, dkk. (eds.). Instrumen Internasional Pokok Hak-Hak Asasi Manusia. Jakarta: Yayasan Obor Indonesia, 2001.

Benedek, Wolfgang and Minna Nikolova (eds.). Understanding Human Rights: Manual on Human Rights Education. Graz, Austia: European Training and Research Center for Human Rights and Democarcy (ETC), 2003.

Dicey, A.V, 1952, Pengantar Studi Hukum Konstitusi, Terjemahan: Nurhadi M.A, Cetakan kedua, Nusamedia, Bandung, 2008.

http://dunia.vivanews.com/news/read/1119_indonesia_menjadi_anggota_pbb_ke_60

Jimly Asshiddiqie. Konstitusi dan Konstitusionalisme Indonesia. Edisi Revisi. Jakarta: Konpress, 2005.

Jimly Asshidiqie, 2008, Menuju Negara Hukum Yang Modern, Sekretariat Jendral dan Kepaniteraan Mahkamah Kontitusi RI, Jakarta,

Katarina Tomasevski, Pendidikan yang terabaikan, terjemahan: Janet Dyah Ekawati, Raoul Wallenberg Institute Of Human Rights and Humanitarian Law bekerjasama dengan Departemen Hukum dan HAM Indonesia, 2003

K.C. Wheare, Konstitusi-Konstitusi Modern, Pustaka Eureka, Jakarta, 2003

McIlwain XE "Charles Howard McIlwain", Charles Howard. Constitutionalism: Ancient and Modern. Ithaca, New York: Cornell University Press, 1966.

Muhammad Yamin. Proklamasi dan Konstitusi Republik Indonesia. Djakarta: Djambatan, 1959.

Soehino, Ilmu Negara, Liberty, Yogyakarta, 2005.

Suharsimi Arikunto, Manajemen Pengajaran Secara Manusiawi. Jakarta: Rineka Cipta, 1990

Surat Kabar Kedaulatan Rakyat 2015.

http://mbajengbremana.wordpress.com/201 3/10/23/7 -kompetensi-pedagogik- sesuaikurikulum-20 13/ diakses pada 15 Oktober 2020 pukul 1 1:40 WIB

Kurnia, H. (2014). PENGARUH KEAKTIFAN BERORGANISASI TERHADAP INDEKS PRESTASI KUMULATIF MAHASISWA UNIVERSITASCOKROAMINOTO YOGYAKARTA. Academy of Education Journal, 5(2). https://doi.org/10.47200/aoej.v5i2.120 
Kurnia, H. (2016). SIKAP NASIONALISME MAHASISWA UNIVERSITAS COKROAMINOTO YOGYAKARTA TAHUN AKADEMIK 2015-2016. Academy of Education Journal, 7(2), 79-88. https://doi.org/10.47200/aoej.v7i2.405

Kurnia, H. (2019). PENGARUH KECERDASAN INTELEKTUAL, EMOSIONAL DAN SPIRITUAL TERHADAP PRESTASI BELAJAR PENDIDIKAN KEWARGANEGARAAN. Academy of Education Journal, 10(01), 1-21. https://doi.org/10.47200/aoej.v10i01.267

Kurnia, H., \& Septera, G. (2019). Penerapan Model Pembelajaran Kooperatif Tipe Make A Match Untuk Meningkatkan Hasil Belajar. Academy of Education Journal, 10(02), 109-121. https://doi.org/10.47200/aoej.v10i02.277

Kurnia, H., \& Widayanti, F. (2020). PENGARUH PENDIDIKAN KARAKTER KEPANDUAN HIZBUL WATHON TERHADAP PRESTASI BELAJAR SISWA DI SMP MUHAMMADIYAH 7 YOGYAKARTA. Academy of Education Journal, 11(01), 75-86. https://doi.org/10.47200/aoej.v11i01.318.

Trianto, Tinjauan Yuridis Hak serta Kewajiban Pendidik Menurut UU Guru dan Dosen. Jakarta: Prestasi Pustaka, 2006

Undang-Undang RI Nomor 14 Tahun 2005 tentang Guru dan Dosen.

Undang-Undang RI Nomor 20 Tahun 2003 tentang Sistem Pendidikan Nasional. 